\title{
THE RUIN OF WHITE ADVENTURERS IN MALAY ARCHIPELAGO, A STUDY TO CONRAD'S TRILOGY: ALAMYER'S FOLLY, AN OUTCAST OF THE ISLAND, AND THE RESCUE
}

\author{
Mugijatna Mugijatna ${ }^{1}$ \\ Faculty Of Cultural Sciences, \\ Universitas Sebelas Maret, Indonesia \\ (Email: ykmugijatna@gmail.com) \\ Sri Kusumo Habsari \\ Faculty Of Cultural Sciences, \\ Universitas Sebelas Maret, Indonesia \\ (Email: skhabsari@stass.uns.ac.id) \\ Karunia Purna Kusciati ${ }^{3}$ \\ Faculty Of Cultural Sciences, \\ Universitas Sebelas Maret, Indonesia \\ (Email: karunia.purna@gmail.com)
}

Accepted date: 04-11-2018

Published date: 11-07-2019

To cite this document: Mugijatna, M., Habsari, S. K., \& Kusciati, K. P. (2019). The Ruin of White Adventurers in Malay Archipelago in Conrad's Trilogy: Almayer's Folly, An Outcast of the Island, and The Rescue. International Journal of Humanities, Philosophy and Language, 2(6), 27-41.

DOI: $10.35631 / \mathrm{ijhpl} .26003$

\begin{abstract}
Many English literary works were written during the colonialism era present white people as superior people. But Joseph Conrad in his trilogy, Almayer's Folly, An Outcast of the Island, and The Rescue, present white people as defeated people. All the main characters in the novels that are white adventures are lost. Almayer, the main character in Almayer's Folly, got bankrupt and eventually died sorrowfully; Willems, the main character in An Outcast of the Island, died at the hand of his beloved; and Lingard, the main character in The Rescue and the character in the other two novels as well, went home empty-handed. Why is the case like that? This research is a study of the trilogy in order to answer the question. Accordingly, the objective is to explain the cause of the white adventurers' lost. This research is conducted using Ricoeur's hermeneutics which consists of distantiation and appropriation as the methodology. The result is that, first, Almayer misunderstood the political situation and misunderstood the mind of her own daughter, Willems was in conflict with Almayer, and Lingard was unlucky; on the other hand, the leaders of the Malay people were crafty, able to make them fight to each other, and able to make a smart move. Second, the novels present objective point of views; from Malay point of views, white adventures in the Malay Archipelago caused miserable life to them but they were too strong to fight against them, while from the point of view of the white adventurers, the Malay couldn't be trusted, cunning, and savage.
\end{abstract}




\section{Introduction}

English literature grew and developed along with the growing and development of Britain (and other West Europe countries) as a colonialist country. As such, in its development English literature produced literary works which later are called colonial literature. In the literary works, the colonized people are presented as inferior-savage people. In Heart of Darkness, Joseph Conrad presents Congo as a dark and mysterious country. The main character of the novel, Marlow, was save because he avoided listening to "appearance", while Kurtz, another character, was mad because he listened to the "appearance" (Calleja, 2003). Mugijatna (2014) in his research on Kipling's short stories found out all the Muslim characters in the short-stories are presented as inferior people, even cruel people. Such kinds of presentation of colonized people in colonial literatures become stereotypical.

Acheraïou in his study on "Karain: A Memory", one of Conrad's short stories, identifies how the narrator who was an Orientalist associated the Malays "with emotionalism and irrationality, standing in sharp contrast to Europe's rationalism and sense of moderation" (2007, p. 154). However, at the same time Conrad also enabled the narrator to see and speak about the European as "unbelief and frantic materialism" that marked the Western also as the radical other (Acheraïou 2007, p. 158).

Achebe criticizes the representation of Congo in Heart of Darkness as racist. On the other hand, Raja (2007, p. 1) says that such kind of accusation on Conrad is too simplifying. He shows how Conrad in his novels on Malays, Almayer's Folly and An Outcast of the Island, cannot be judged simply as racist. He writes, "Hence, I suggest, Conrad should neither be read as the so-called "thoroughgoing racist" of the Heart of Darkness or as "a remarkable man" $[. .$.$] , but rather as an ambivalent writer of his times who, at times, was able to go$ beyond the realm of the cultural stereotype and colonial prejudice" (Raja, 2007, p. 12).

In this research, we study Conrad's trilogy which consists of Almayer's Folly, An Outcast of an Island, and The Rescue. In the three novels, Conrad presents three white adventurers in Malay Archipelago as defeated people. Why is the case like that? It is interesting to study the case because the case clearly shwos that Conrad goes beyong cultural stereotype and colonial prejudice as identified by Raja. It is contradictory to most of colonial literary works which always present white people as the winning people and the coloured people as the defeated ones. Even a very recent reserach on post-colonial era travel writing found out how the narrative in the travel writing "continues the colonialist tradition when the natives of Sarawak and their land are cast as the inferior 'Other' through various negative representations." (Chandra and Vengadasamy, 2018, p. 9).

Accordingly, the objective of this research is to explain the cause of the ruin of the white adventurers in the trilogy by Conrad, Almayer's Folly, An Outcast of the Island, and The Rescue. Lane's judgement (1999, p. 421), that "Conrad's European males seem especially disposed to suffer because their arrogance blinds them to other forms of existence", is made from European perspective. What abaut from the perspective of colonizeds, what about the colonizeds' role in ruining the white adventures? 


\section{Literature Review}

\section{Hermeneutics}

Hermeneutics is a philosophy of understanding developed by German phylosophers. The term Hermeneutics derives from "herme>neuein" which means "to interpret" and a noun"herme>neia" which means "interpretation" (Palmer, 2003, p. 14). The word is connected to Hermes, a god in Greek Mythology, one of whose duties is to convey Zeus' message, the highest god, to human being (Sumaryono, 1993, p. 23). Connected to the root of the word, modern word of "Hermeneutics" assumes a process of coveying something to understand (Palmer, 2003: 15).

Modern Hermeneutics is introduced the first time by Schleiermacher in his seminal book, Hermeneutik und Kritik mit besonderer Bezeiehung auf das Neue Testament publihsed in 1883. In 1900, Dilthey continued Schleirmacher thought in his writing "Entstchung der Hermemeutik". (Murray, 1975, p. 64). Now Schleiermacher and Dilthey are known as 'The undisputed founding fathers of the German Hermeneutics tradition. (Goring, et.al., 2001, p. 152). Dilthey continued thought on Hermeneutics as method on social sciences and humanities which interpret human being's psychological expression. The keyword of human sciences is verstehen (understanding), while the keyword of natural sciences is erklaren (explaining). So, Dilthey differentiates human sciences from natural sciences and he is the first person who conducted research on the process of understanding. (Puspowardojo, 1987, p. 51-54).

Heidegger who took Hermeneutics directly from Schleiermacher and was followed by Gadamer developed Hermeneutics not as method of understranding, but as philosophy of understadnjing, so that there are differences between Schleiermacher and Dilthey's tradition from Heidegger and Gadamer's tradition. The followers of Schleiermacher and Dilthey's tradition regard Hermeneutics as a body of methodological principles underlying understanding. The followers of Heidegger and Gadamer's tradition regard Hermeneutics as phylosophical exploration to the traits and condition for understanding (Goring, et. al., 2001, p. 153).

\section{Ricoeurean Hermeneutics}

As used by Mugijatna, et. al., (2014; 2019), in this research we follow Ricoeur's Hermeneutics which entails method of understanding literaty texts. In "Phenomenology and Hermeneutics", Ricoeur (1975, p. 80) says that the common trait of text "which constitutes the text as text is the fact that the meaning of the text has become autonomous in relation to the intention of the author, the critical situation of discourse, and its first addressee" and that critique of ideologies in self-comprehension "rest on the element of distantiation" (p. 92). What he means by distantiation (this word is also spelled "distanciation") is "the dialectical counterpart of belonging-to, in the sense that our manner of belonging to a historical tradition is to be related according to a distance which oscillates between remoteness and proximity". So, according to Ricoeur, "the hermeneutical task is to discern the "thing' of the text (Gadamer) and not the psychology of the author." He says that "The question is no longer to define Hermeneutics as an inquiry into the psychological intentions which are hidden in the text, but as the explication of the being-in-the-world shown by the text. What is to be interpreted in a text is the projection of a world which I could inhabit". Relying on the theory of text as guidance, Ricoeur concludes that the act of subjectivity is made the last, not the first, "this conclusive act could be expressed as appropriation". It is not "the original 
subjectivity which carried the meaning of the text. It responds instead to the thing of the text. It is therefore the counterpart of distantiation which established the text in its own autonomy in relation to the author, to its situation, and to its original destination." (p. 92-94). Appropriation is to attain self-understanding, "to understand is to understand oneself in front of the text" (Simms, 2003, p. 42). This means that to do Hermeneutics is to understand life exposed by the text.

In an inetrview with Erik Nakjavani, Ricoeur explains the methodology more clearly; he says that "The first task of phenomenological approach to the problem of literature would be to define the boundaries of the idea of the text." In answering his own questions of "What is a text?", Ricoeur starts with another question, "what are the fundamental characteristics of discourse?". According to him "there is already a specific feature of discourse, in comparison to language, which constitutes the first boundary of the literary object". First, among other traits of discourse, "It is away of revealing a dimension of reality in relationship to a dialoge with another person. There is in it a triangular relationship, the one who speaks, the one who listens and answers, and the world one talks about. The second, "from the point of view of listeners, the writing slips away from the speaker, since writing has the power to preserve the discourse after the destruction and disapperance of the speaker. So there is an autonomy of text." The third, "the world is openned up in this manner by writing is itself also a world which has an infinite horison". So, the text is something to be interpreted. (Nakjavani, 1996, p. 90-91).

"So, since the text has an autonomy in relation to the writer, and also in relation to the writer, one may certainly treat it primarily as a thing which is completelly independent, both of the writer and the reader, and one may treat it as an absolute object." Ricoeur reference is French structuralists, anyhow, it echoes the aponion of New Criticism ideas on the autonomy of text. In "Intentional Fallacy" and "Affective Fallacy", Wimsatt and Beardsly (1972A; 1972B) efface both the authors and the readers from the enterprise of understanding literary works. According to Ricoeur, the objective undertaking is legitimate, but it is "merely an abstract and preparatory phase for an appreciation of the text from which we make our own flesh and blood through a sort of appropriation which makes from what was strange something appropriate and familiar.". (Nakjavani, 1996, p. 92).

\section{Methodology}

The methodolgy chosen to solve the problems was qualitative metodhology. The data consisted of words, sentences and paragraphs. Accordingly, this research employed qualitative analysis, no quantative measurement was employed. Based on the theory of hermeneutics, the methodology of this research consisted of three steps: objective reading, contextual reading and interpretation. The objective reading was conducted by employing narrative analysis (Mugijatna, et. al., 2014; Mugijatna, et. al., 2019), that is, plot and character analysis. The contextual reading was conducted by putting the finding of the objective reading in the context of colonialism in Malay Archipealgo. The interpretation was counducted through deductive analysis. 
The methodology can be described in a chart as follows.

\section{Figure 1}

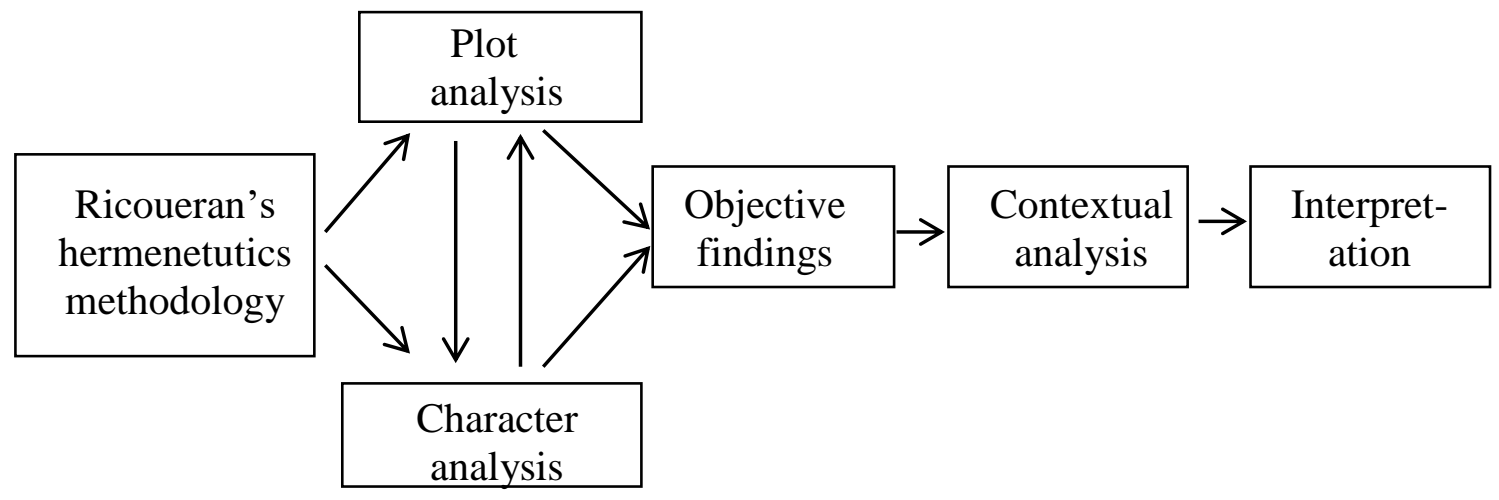

The data consisted of main data and supporting data. The main data were taken from the three novels by Conrad, Almayer's Folly, An Outcast of The Island, and The Rescue. The supporting data were taken from other writing materials like articles published in proceedings and jorunals. The data were taken using qualitative content analysis. Content analysis is a method of data collection from documents (Marshal and Rossman (1995); novels and other writing materials belong to document.

The analysis which consisted of objective analysis and contextual analysis was, first, to describe life exposed by the three novels. By means of plot and character analysis, the life exposed by the novel could be described. The second, the life exposed by the three novels, then, was compared with colonialism in Malay Archipelago. By means of deductive analysis the ruin of the white adventurers in the three novels could be understood. The process from data collection up to conclusion was conducted interactively (Miles and Hubeman, 1984).

\section{Result and Discussion}

\section{The Ruin of Almayer in Almayer's Folly}

Almayer is the main character of Almayer's Folly. When he was working in Macassar in the godowns of old Hudig, he met Tom Lingard, of whom the Malays recognised as "the Rajah-Laut" - the King of the Sea. "Almayer had heard of him before he had been three days in Macassar, had heard the stories of his smart business transactions, his loves, and also of his desperate fights with the Sulu pirates, together with the romantic tale of some child - a girl - found in a piratical prau by the victorious Lingard, when, after a long contest, he boarded the craft, driving the crew overboard." (Conrad, 2018A, chapter 1, p. 3/11). The girl who was only 14 years old couldn't jump overboard because she was wounded. Lingard saved the girl, adopted her as his daughter, got her educated in a nun in Semarang, and then married her to Almayer. From the marriage they got a daguhter, Nina Almayer.

Lingard had found a river in Sambir, Borneo, and built a trading-post in a new settlement developing there. The sttlement was at the bank of a river which became the means of transportation. Lingard placed Almayer there as his represenative; he built an office for Lingard \& Co and a house for Almayer and his wife. After establishing the office and 
placing Almayer there, Lingard went again for another adventure. Almayer "was very soon made to understand that he was not wanted in that corner of it where old Lingard and his own weak will placed him, in the midst of unscrupulous intrigues and of a fierce trade competition." The Arabs had also found the river and built trading-post there and "Lingard returned unsuccessful from his first expedition, and departed again spending all the profits of the legitimate trade on his mysterious journeys." (Conrad, 2018A, chapter 1, p. 3/9). Almayer struggled with the difficulties himself, friendless and unaided. His trade fell away from the large go downs and his fortune was gone.

Now his obsession was to get gold found by Lingard; he found out Lingard's pocket book in which Lingard made scrabble notes of the gold. Dain Maroola, the son of the king of Bali, who went to Sambir to buy guns, promised to help Almayer to make expedition to find the gold-mine in return to Almayer's willingness to buy guns for him from Singapore. It made Almayer happy; to his daughter, Nina, he said "'we shall be happy, you and I. Live rich and respected far from here, and forget this life, and all this struggle, and all this misery!'” (Conrad, 2018A, chapter 1, p. 9/11). But, it was really because Dain Maroola had caught sight of Nina and loved her and Nina aslo loved him. Dain's often visiting Almayer's house afterwards was to meet Nina behind Almayer's house under the watch of Mrs. Almayer's, who was glad to know Dain Maroola loved her daughter, in case Mr. Almayer suddenly appeared there.

Dutch found out that Dain Maroola's coming to Sambir was to buy guns illegally and pursued him to Sambir. But Babalatchi, Lakamba's Prime Minister, and Mrs. Almayer cheated them. They dressed one of Dain's men who had died before with Dain dresses. They put Dain's ring on the finger of the death body, Dains' anklet on the anklet of the death body, Dain's sarong on the death body, and made the death body entangled by logs floated on the river to create an image that he died of being drowned by flood. To make the death body unidentifiable, the face of the death was destroyed. When early in the morning the dead body was found out, Babalatchi made all people, including Almayer, believed that it was Dain Maroolla. Almayer was shocked, he said to her daughter "Dain dead, all my plans destroyed. This is the end of all hope and of all things." (Conrad, 2018A, chapter 8, p. 9/12). When Dutch men of war boats asked Almayer about Dain Maroola, Almayer showed the dead body to them.

Dain Maroola was saved and when Almayer knew that the death body was not Dain, he pursued Dain and his daughter to their hiding place. He asked Nina not to follow Dain Maroola, "'tell me, what have they done to you, your mother and that man? What made you give yourself up to that savage? For he is a savage. Between him and you there is a barrier that nothing can remove" (Conrad, 2018A, chapter 11, P. 8/14). But Nina who had been sent to Singapore to get European education there refused to return back to his father and Almayer's heart was broken. He said that he wouldn't forgive her and would forget her soon, but he couldn't forget her and eventually died sorrowully.

The plot analysis shows that Almayer's ruin was due to his folly and crafty Malays. His folly made her unaware of the changing political situation which made Lakamba and the Arab more favourable to the Dutch rather than Almayer eventhough he was Hollander. The crafty Malays made Almayer a fool; before the coming of the Dutch men of the-war-boats to catch Dain, Babalatchi and Mrs. Almayer cheated Almayer to believe that Daid Maroola had been drowned in the flood and died, while he didn't. 
The life exposed by the novel is a life in a river bank in which white people lived together with Malays and Arabs. Nina compared life in Singapore with life in Samber as described in the following figure 2 .

\section{Figure 2}

Life in Singapore Life in Sambir

Trade in brick godowns

Made love in the cathedral of Singapore promenade

Made a plot under the protection of laws under the rules of Christian conduct
Trade in moddy river bank

Made love under the shadows of the great trees

Saught the gratification of desires with savage cunning and the unrestrained of fierceness of natures

The white people, on the one hand, and the Malays and Arabs, on the other hand, were hostile to each other. The white people wanted to dominate and monopolize the trade there through winning political influence from the Rajah, and the Malays and Arabs fought against them through crafty deeds. The white people were lost and Almayer, the only representative, died sorrowfully.

\section{The Ruin of Willems in An Outcast of The Island}

The events of the plot of An Outcast of the Island happened before the events of the plot of Almayer's Folly. Willems, the main character of An Outcast of the Island, was found by Lingard in Semarang when Willems was only a boy of seventeen years old. He run away from a Dutch ship and asked Lingard to allow him to join his ship. Lingard made him accepted by Hudig \& Co and Hudig, then, married him to his daughter, Joanna. He was smart and successful so that his wife and her family adored him. But, due to a misconduct in Hudig \& Co that was recognised by Mr. Vinck, the treasurer, his wife and her family didn't respect him anymore. Willems reputation was collapsed and his wife drove him out from the house for the hause was a gift from his father to her. On an evening, when Willems was roaming here and there, Lingard who had already heard of his misfortune, found him and took him to Sambir to help Almayer. But Almayer disliked Willems from the very start; when they were working in Hudig \& and Co and Willems was Almayer's senior, Willems treat him unfavourably.

Lingard told Willems that the Rajah of Sambir, Patololo, was at his hand. His words were law in Sambir. He didn't allow the Malay traders traded with other traders than himself. Abdulla, the Arab trader was jealous to his comercial and political success. When arriving in Sambir, Lakamba, a Malay adventurer, was disappointed to know that in Sambir there had been an organized sosiety and acknowledged Patalolo as the Rajah. He led a move by Bugis settlers against Patalolo, but Lingard suddenly appeared and stopped him and menaced him. Lakamba then turned to become half-trader and half-rice grower, while still keeping his disappointment. Babalatchi, a Malay of Sulu origin, who run away from Sulu to Sambir together with Omar el Badavi, who was once a brave fighter and the leader of Borneo rover but now old and blind and was attended only by his daughter Aissa, fanned Lakamba's disappointment. Patalolo only received Omar el Badavi so that Babalatchi went to Lakamba for refuge. He knew Willems' quarell with Almayer and Willems' love-affair with Aissa; due 
to his quarell with Almayer, Willems, one day, was canoeing alone and when he entered a small creek he met Aissa; he was stunned by Aissa's beauty and they, then, love each-other. Babalatchi suggested Lakamba to make use of Willems' quarell with Almayer and his love affair with Aissa to destroy Lingard's influence on Patalolo. Lakamba agreed upon Babalatchi's scheme and they persuaded Omar el Badavi and Aissa to move (or kidnapped) to Lakamba's compaund so that they could control Aissa and Willems who loved her desperately. In the meantime, Babalatchi asked Abdulla for help to support them with guns and money. Through Aissa, they persuaded Willems to command their move to Patalolo. because Patalolo's water gate was closed and barred he entered Patalolo's stockade by force. The presence of Abdulla who was a very rich trader and was favourable to Batavia made Patalolo agree to deliver his power to Lakamba; Patalolo only wanted to be allowed to do pilgrimmage to Mecca. Babalatchi and Willems raised Holland's flag to be saluted by all who passed under it. Jim-Eng, a China man, didn't want to salute the flag because he was a British subject. He run across the river to Almayer's house who, as a defence to himself, raised Union-Jack, British flag. Lakamba's follower run after him; Willems and Aissa were among them. They plundered Almayer's house and Willems tied Almayer's to his chair to humiliate him. Aissa made a hint to Willems to kill Almayer, but Willems told Almayer that not a hair of him would be touched.

Lingard who, then, arrived in Sambir taking with him Joanna, Willems's wife, and her son, was angry to find what had been done by Willems. He didn't allow Willems to leave the place where he was with Aissa, he made Willems his prisoner there. When Joanna and her son appeared at the place, Aissa was shocked. Willems wanted to go from the place, but he couldn't go without any guns at his hand. Aissa kept the revolver and Willems asked Aissa to give the revolver to him, but Aissa refused and when Willems went closer to her to get the revolver by force, Aissa pointed the gun at him. Believing that Aissa's shot would miss, he lowered his body while reaching the gun from Aissa's hand, but Aissa's shot didn't miss, the bullets hit Willems and Willems died.

The plot analysis shows that the main cause of Willems' death was his qualler with Almayer. But the root of it was his own character, he was conceited so that he belived that Hudig \& Co wouldn't have discovered his unfair dealing. For Babalatchi who was crafty and cunning, Willems' being unfriendly with Almayer and loving Aissa was an opening to enter in order to lead Willems into the center of the conflict between Almayer and Lakamba. And he died.

The life exposed in An Outcast of the Island is the same as the life exposed in Almayer's Folly. The difference is that the main character in An Outcast of the Island, Willems, is a lowcaste European, while Lakamba and Babalatchi are the same Lakamba and Babalatchi in Almayer's Folly: crafty and cunning. Even, it is in this novel how Lakamba and Babalatchi ruined Almayer trade in Sambir is narrated, they drove out Patalolo who had protected Almayer.

\section{The Ruin of Lingard in The Rescue}

The Rescue is the stoy of Lingard adventure. Once, Pata Hassim, a Wajo prince and trader, saved him from Papuan people who attacked him. Lingard landed at the coast of the island unarmed for unimportance things like to get water and Hassim who was amazed to see Lingard went inland unarmed followed him to know what would happen. Hassim who used to go there was true, the Papuan attacked Lingard and Hassim fired shots to make them retreat. Lingard who, then, invinted him to his ship, liked Hassim; he swore that Hassim's cause would also be his cause. Even then he ragarded Hassim and his sister, Immada, like his 
own children. When his great uncle died and Hassim, the right inheritance of the crown of Wajo, was dirven out by the son of his uncle, Lingard saved him. Lingard promised to help Hassim to regain his crown. While going here and there to get alliences and money as preparation to attack Wajo, he had Hassim and Immada stay in Belarab settelment at The Sea of Refuge. When young, Belarab together with his father was a partisan in Padri War and when Mingkabau's learders invited Dutch to interfere Belarab run to the sea unknown by Dutch; due to it the sea was called The Sea of Refuge. Lingard bought a wrecked ship, Emma, to store guns and placed the wrecked ship in a hidden islet, guarded by his friend, old Jorgenson who was also a partisan in Padri war, supported by Hassim's followers.

Suddenly a British ship in her voyage to Batavia was stranded at the sea to perplex Lingard for the ship's would disturb the quiet sea. Lingard told the owner of the ship, Mr. Travers, "The sea is free to all of us. Some work on it, and some play the fool on it - and I don't care. Only you may take it from me that I will let no man's play interfere with my work. You want me to understand you are a very great man - ". (Conrad, 2018C, p. 71). Lingard was perplexed more when Mr. Travers, who regarded Lingard as a untrustworhty person, and his friend, D'Alcacer, were kidnapped by Daman, one of Lingard alliances, for ransom. Daman was the head of the Illanuns, piratical and blood thirsty Malys from the north, and was hosted by Tengga for Belarab didn't wat to host him. Tengga lived in Belarab's settlement and was excited by the desire to replace Belarab as the head of the settlement. Mrs. Travers, the wife of the owner of the ship, urged Lingard to save her husband and his friend. Daman kept Mr. Travers and D'Alcacer in his camp in Tengga's settlement and Lingard through high deplomacy had Mr. Travers and D'Alcacer removed to Belarab's stockade.

To make the situation more complex, Tengga's men wanted to plunder the stranded ship and Tengga himself told Jorgenson that he could capture Emma to get the guns stored there for he had more men that Hassim's followers who guarded Emma. Daman also wanted to have the powder stored in Emma, he asked Jorgenson to give him powder, he would like to procced to Wajo. Jorgenson refused Daman's request, eventhough Immada suggested Jorgenson to give Daman the powder. Jorgenson would give the powder to Daman only when Lingard was present. Tengga sent an envoy to invite Jorgenson to have a friend talk with him, he convinced Jorgenson that now Hassim and Immada were save with Tengga; Tengga's men had seized Hassim dan Immada as hostages when they were on the way to return from Belarab's father's graveyard to join Lingard in his brig. Instead of fulfilling the envoy's inviation, Jorgenson told him that he would receive Tengga on board of Emma as long as he brought with him Hassim and Immada. At the time, Lingard was at Belarab's stockade to take away Mr. Travers and D'Alcacer from Belarab's stockade. When Lingard was about to leave the stockade together with the captives, Belarab and Lingard through long glass saw Emma was surounded by war boats. Daman and Tengga were on aboard of Emma, including Hassim, Immada, and Jaffir, Hassim's faithfull follower. Tengga told Jorgenson that Lingard had become a willing captive at Belarab's stockade and had been possessing no more power than a dead man, the mere slave of those strange white people and Belarab's prisoner. Tengga asked Jorgenson to give up the arms and everything that was stored in Emma to himself and to Daman. Jorgenson and Jaffir were expecting a signal from Lingard who was in Belarab's stockade. But no signal was sent by Lingard. Jorgenson who was in the midst of twenty spear-blades that could in an instant have been driven into his breast, put the cigar in his mouth and jumped down the hatchway where the guns were stored. Suddenly, the wrecked ship blown up to pieces. Those who were on borad of the ship, Daman, Hassim, Immada, and Jorgenson himself, all died, except for Jaffir who had jumped overboard just in time, but wounded heavily and died after telling the events to Lingard. In his stockade, Belarab, 
Lingard, and the white captives all saw the events. The Emma's being blown up made up Belarab's mind that now Lingard was no longer a man of any importance. He wanted "to see all the white people clear out of the lagoon as soon as possible". When leaving Belarab, Lingard said, "You shall never see me again" (Conrad, 2018C, p. 250). Lingard, the Rajah Laut to whom Malays were afraid of, went home empty handed.

The analysis of the plot shows that Lingard's adventure in Malay Archipelago ended in failure due to his being unlucky. The British ship's being stranded at the shore was his being unlucky. If there was no any British ships stranded there, his "project" to return Hassim and Immada to their kingdom might have been successful. But, there was and his "project" failed. When Mrs. Travers asked him, "What can there be at stake?" [...]. "Lingard said, "A kingdom" (Conrad, 2018, p. 93).

He succeeded in rescuing the owner of the stranded ship and his friend, but his "project" failed and his belonging and his power as the Rajah Laut in Malay Archipelago was destroyed. His farewel sentence to Belarab, "You shall never see me again", implies the end of his adventure in Malay Archipelago.

The analysis of the plot also shows the life exposed by the novel, that is, complex relationship of multy races: Britishes, Spaniard, Arabs, and Malays. The relationship was knitted by the Europeans' adventure and trade in Malay Archipelago and the responds made by Malays and the Arabs who had been living and trading in Malay Archipelago. In the complex relationship, the Europeans made friends with some Malays but, at the same time, fought against some other Malays. Some of the Malays also befriended with the Europeans, while some other Malys were hostile to the Europeans.

According to Young (1953, p. 524), Lingard's ruin is a criticism to "a devastating error of the White Man's Burden-meddling in alien politics, killing natives, stranding the lives of its lower-class whites, defending the lives of the higher-class ones, all from the mandates of arrogant philanthropy". It is a criticism to Kipling's ideology on colonialism.

\section{The Presentation of Malays from White Colonialists' Point of Views}

For the colonialists, colonialism was good for the colonizeds, for colonilaism civilized the colonizeds. Regarding British colonising Egypt, for example, Balfour, as quoted by Said (2003, P. 33), said, "It is a good thing for these great nations - I admit their greatness [...] I think that experience shows that they have got under it far better government than in the whole history of the world they ever had before, and which not only is a benefit to them, but it undoubtedly a benefit to the whole of the civilized West ...". The last sentence, that British occupation over Egypt is "a benefit to them" and "a benefit to the whole of the civilized West" needs to be noticed: it demonstrates the colonizers' opinion on the colonizeds that their civilization is far better that civilization of the coloniseds. This opinion is explicitly stated by Kipling concerning India: "the British were helping to civilize and educate a previously 'savage' people. They were doing good deeds." (Kipling, 1899).

Almayer's opinian, in Almayer's Folly, is the same, he regarded his wife, Mrs. Almayer, and Dain Maroola, who was the son of the king of Bali, "savages". He stated the opinion when giving advice to his daughter, Nina, not to follow Dain Maroola: "'tell me, what have they done to you, your mother and that man? What made you give yourself up to that savage? For he is a savage. Between him and you there is a barrier that nothing can remove'." (Conrad, 2018A, chapter 11, p. 8/14). Lingard's advice to him not to kick his wife because he was 
white betrays common opinion and attitude of white people towards Malays. "And don't you kick because you're white." The advice shows how white people regarded Malay people, except for Lingard, as savages.

The most representative colonialist's opinions and attitudes on Malays were the opinion and attitude of Mr. Carter and Mr. Travers in The Rescue. Mr. Carter, the man of Mr. Tavers, when boarding Lingard's brig to take over the brig under his command, while Lingard was going away to Daman camp bringing with him Mrs. Travers to negotiate the transfer of Mr. Travers and D'Alcacer to Belarab's stockade, and seeing Hassim and Immada, he said huskily, "Niggers," [...] "In the cuddy! In the cuddy!" [...] "I can't have it," [...] "Damme! I've too much respect for myself." [...] "Out you go" [...]. "They ain't friends of mine. I ain't a vagabond. I know what's due to myself. Quit!". (Conrad, 2018C, p. 137). It shows how colonialist and racist he is.

Mr. Travers, more intelectual, said that colonialism is a duty to civilize, "An international understanding - the duty to civilize "”, so that, even, if the colonizeds must perish it is just the aim of progress, "And if the inferior race must perish, it is a gain, a step toward the perfecting of society which is the aim of progress." (Conrad, 2018C, p. 86-87). The opinion is the semblance of the very core of the ideology of colonialism hold strongly by the colonialists like Balfour and Kipling.

Such presentation of colonialists is objective presentation: the colonialists are presented as colonialists who perceived themselves as superior and civilized and perceived the colonizeds as inferior and savage that needed civilizing.

\section{The Presentation of White PeoplefFrom The Point of Views of Malays}

As if to contradict Balfour and Kipling's ideology on colonialism, Soekarno, the first Indonesian president who before the declaration of independence had been one of the leaders of movements for Indonesian independence, in his writing published in 1928 says that the colonialism is not a matter of civilizing savage people, the burden of white people, instead it is a matter of business, a matter of lost and benefit, a matter of life, "'Soal jajahan adalah soal rugi atau untung; ini bukanlah soal kesopanan atau soal kewajiban, soal ini ialah soal hidup, soal business." (Soekarno, 2015, P. 51). The coming of white people to East countries like Indonesia and India was to trade; they were traders whose aims were to get benefit. VOC in Indonesia and EIC in India were trading companies supported by soldiers. In their trade activities they conquered lands and kings and when they were got bankrupt their home government took over the countries they conquered and placed the countries under the home countrie's direct government, consequtively, Dutch and Britain.

Soekarno, even, describes and compares Dutch with Rahwana, the giant with ten heads and ten mouths. In his writing published in 1933, he writes, "Raksasa 'biasa' yang dulu berjengkelitan di atas padang kerezekian Indonesia, kini sudah menjadi raksasa Rahwana. Dasamuka yang bermulut sepuluh." (Soekarno, 2015, P. 299). On page 331 of the same article, the metaphor is expanded to include other imperialists,

Raksasa modern-imperialisme yang ada di sini, kini bukan lagi raksasa biasa, tetapisudah menjelma jadi raksasa Rahwana Dasamuka yang sepuluh kepala dan mulutnya badannya imperialisme Belanda, tapi badan ini memikul kepala imperialisme Inggris, kepala imperialisme Amerika, kepala imperialisme Jepang, kepala imperialsime Prancis, Jerman, Italia dan lain-lain." 
Raksasa (giant) is a character in leather puppet show representing greed and cruelty. Leather puppet show is Javanese traditional theatre, the source of the reportoire of which is Mahabarata and Ramayana. Rahwana is the antagonist in Ramayana. He stole Sinta, Rama's wife.

In Almayer's Folly, Mrs. Almayer, in whose personality West-Christian education in a nunnery in Semarang left only supersitious belief in Cross so that she remained a Malay woman, advised her daughter to forget everything about the white people when her daughter was going to join Dain Maroola in his hiding place. Mrs. Almayer said,

"Give up your old life! Forget!" [...]. Forget that you ever looked at a white face; forget their words; forget their thoughts. They speak lies. And they think lies because they despise us that are better than they are, but not so strong. Forget their friendship and their contempt; forget their many gods." (Conrad, 2018A, chapter 10, p. 3/12 - italic by us).

Nina herself, whose West-Christian education she received in Singapore didn't leave any trace in her too, even not any any single Cross, effaced by her mother's story of Sulu rajahs and warriors. hated white faces. She told it to the Dutch soldiers who were seeking for Dain Maroola and were seeking for information from her father of where Dain was.

"I hate the sight of your white faces. I hate the sound of your gentle voices. That is the way you speak to women, dropping sweet words before any pretty face. I have heard your voices before. I hoped to live here without seeing any other white face but this." (Conrad, 2018A, chapter 9, p. 9/13). What she meant by "but this" is her father.

She wanted them to go away from his father's verandah soon. And when she asked her mother, "but where is my power, and what can I do?", Mrs. Almayer said,

"Do not let him look too long in your eyes, nor lay his head on your knees without reminding him that men should fight before they rest. And if he lingers, give him his kriss yourself and bid him go, as the wife of a mighty prince should do when the enemies are near. Let him slay the white men that come to us to trade, with prayers on their lips and loaded guns in their hands. Ah!" (Conrad, 2018A, Chapter 10, p. 3/12 italic by us).

Mrs. Almayer's description of white men who traded in colonized countries "with prayers on their lips and loaded guns in their hands" is stricking, it echoes colonialism maxism, "Bible on one hand and gun on the other hand".

Nina herself regarded life in civilised Singapore and savage life in Sambir were the same, both were the manifestation of hate and love and of lust for money.

Babalatchi, in Almayer's Folly, described Almayer as a white man who thirst for dollar, and to Lingard, in An Outcast of the Island, when Lingard told Babalatchi that his speak to Patalolo like an elder brother was for the good of all, Babalatchi said,

"This is a white man's talk," [...]. "I know you. That is how you all talk while you load your guns and sharpen your swords; and when you are ready, then to those who are weak you say: 'Obey me and be happy or die!' You are strange, you white men. You think it is only your wisdom and your virtue and your happiness that are true. You are stronger than the wild beasts, but not so wise. A black tiger knows when he is not hungry - you do not. He knows the difference between himself and those that can speak; you do not understand the difference between yourselves and us - who are 
men. You are wise and great — and you shall always be fools." (Conrad, 2018B, p. 136).

The sentences made us remember Karl Marx's comment when England or, rather, East Indian Company, made war with Persia. In the article written in 1856, "Anglo-Persian War", he says,

So soon as the company casts a greedy look on any of the independent sovereigns, or on any region whose political and commercial resources or whose gold and jewels are valued, the victim is accused of having violated this or that ideal or actual convention, committed some nebulous outrage, and then war is declared, and the eternety of wrong, the perennial force of the fable of the wolf and the lamb, is again incarnadined in national history. (Marx, 1968, p. 91).

The argument of the wolf to eat the lamb in the fable of "The Wolf and the Lamb" used by EIC in $19^{\text {th }}$ century to occupay Persia was used again in $21^{\text {th }}$ century by George W. Bush to attack Iraq for Iraq is rich with oil.

Such kind of presentation of white people by Malays is also done by Malay characters in The Rescue. Daman had his men kidnap Mr. Travers and D'Alcacer was because, according to him, the white people were sent by their rulers to examine the place, the beginning of sorrows,

Why, asked Daman, did these strange whites travel so far from their country? [...]. Evil would follow in their footsteps. They were such men as are sent by rulers to examine the aspects of far-off countries and talk of peace and make treaties. Such is the beginning of great sorrows. [...]. He asked what they had come to see? Was there nothing to look at in their own country? (Conrad, 2018C, p. 128).

The analysis clearly shows how the presentation of white people by Malays is objective presentation. The Malays disliked colonialism in Malay Archipelago.

\section{Friendly White People Toward Malays and Vice-Versa}

White people friendly to Malays in the trilogy regard the Malays positively and vise-versa. To Hassim and Immada, Lingard, the Rajah Laut, was gentle. When Immada said that he had already forgoten them, he said, "'There was too much trouble in my eyes,' with patient gentleness of tone and face." (Conrad, 2018C, p. 80). To all Malays friendly to him, he was gentle. He regarded Wasub, his serang, was dependable. And Jaffir, Hassim's follower and messanger, was praised highly, not only by Lingard, but also by Jorgenson and Mr. Carter.

Mrs. Travers was also gentle to Immada, "Almost a child! And so pretty! What a delicate face," [...]. "I had no idea of anything so charmingly gentle," [...]. "So young! And she lives here — does she? On the sea - or where? Lives —" [...] "How does she live?". [...]. "I hope," [...], "that this poor girl will know happier days —" (Conrad, 2018C, p. 82-83). The quotations show that Mrs. Travers is not racist.

The revers, Hassim and Immada also behaved positively, not only to Lingard, but also to Mr. Travers and his wife, Mrs. Travers. Hassim, alone, approached Daman camp and went in to know how Mr. Travders and D'Alcacer were treated by Daman. While his sister, Immada, gave Mrs. Travers the best of her dress to be put on by Mrs. Travers when she followed Lingard to negotiate with Daman to move Mr. Travers and D'Alcacer to Belarab Stockade. Immada gave her clothes to Mrs. Travers and showed her how to put them on. 
The objective presentation makes the Malays real Malays and the whites real whites. Conrad voyage to Malay Archipelago and his encounters with Malay people makes him able to portray Malays as Malays. The first sentence in Almayer's Folly, "Kaspar! Makan!", one word of which is Malay word, and many other Malay words in the trilogy demontrate that Conrad is falimiar with Malay people and culture. All of that make Conrad seems to go beyond racism and colonialism, while the fact may be because he wants to present realistic presentation of Malay people.

\section{Conclusion nd Recomendation}

\section{Conclusion}

The conclusion is that the ruin of the white adventures in Malay Archipelago is due to two factors. The first, the ruin of Almayer in Almayer's Folly is because Almayer misunderstood the political situation and misunderstood the mind of her own daughter, the ruin of Willems in An Outcast of the Island is because of his conflict with Almayer which is the outcome of his character, and the ruin of Lingard is because he is unlucky. The second, the leaders of the Malay people are crafty, able to make the white people to fight to each other, and able to make a smart move.

The novels present objective preseentation; from Malays' point of view, the presence of white adventures in Malay Archipelago causes miserable life to them but they are too strong to fight against, while from the point of view of the white adventurers, the Malay cannot be trusted, cunning, and savage. From the point of views of white people and Malays friendly to each other, the presentation of both are positive; the white people are gentle to the Malays and the Malays are helpfull to the white people. The objective presentation entails an impression that Conrad in the trilogy goes beyond racism and colonial prejudice.

\section{Recommendation}

The trilogy has strong historical background of colonialism in Malay Archipelago. They are rich with references to historical facts. Research focusing on the relationship of the trilogy with the historical background will be very useful. The result of such a research will be very beneficial for the understanding of the relationship between Malay people and white people in the past fostered by colonialism. The past encounters may leave traces up to the present time in wich the relationship between Malay people and West people becomes more intenship and occurs in many aspects. New historicism may be used as the approach in the research, for new historicism pays attention to both.

\section{References}

Conrad, J. (2018A). Almayer's Folly. eBooks@Adelaide, The University of Adelaide, Library University of Adelaide, South Australia 5005. Retrieved 30/4/2018 from https://ebooks.adelaide.edu.au/c/conrad/joseph/c75al/.

Conrad, J. (2018B). An Outcast of the Island. eBooks@ Adelaide, The University of Adelaide, Library University of Adelaide, South Australia 5005. Retrieved 30/4/2018 from https://ebooks.adelaide.edu.au/c/conrad/joseph/c75ou/index.html.

Conrad, J. (2018C). The Rescue. eBooks@ Adelaide,The University of Adelaide, Library University of Adelaide, South Australia 5005. Retrieved 30/4/2018 from https://ebooks.adelaide.edu.au/c/conrad/joseph/c75r/.

Calleja, M. A. A. (2003). Joseph Conrad's Heart of Darkness as a Journey in Quest of the Self. Odisea, (4), 7-16. 
Chandran, R; Vengadasamy, $R$. (2018). Colonialist Narrative in a Post-Colonial Era Travel Writing, Into the Heart of Borneo. GEMA Online ${ }^{\circledR}$ Journal of Language Studies Volume 18(4), pp. 11-25. Retrived on December 4, 2018 from http://doi.org/10.17576/gema-2018-1804-02.

Goring, P., et. al. (2001). Studying Literature. London: Arnold.

Kipling, R. (1899). The White Man's Burden. Modern History Sourcebook. Fordham University. Retrieved on May 26, 2014, from http://legacy.fordham.edu/halsall/mod/kipling.asp.

Lane, C. (1999). Almayer's Defeat: The Trauma of Colonialism. A Forum Fiction, 32 (3), 401-428.

Marshal, C. and Rossman, G. (1995). Designing Qualitative Research. Second Edition. California: Sage Publications.

Marx, K. (1968) Anglo-Persian War. Engels, F. and Marx, K. On Colonialism. Moscow: Foreign Languages Publishing House, 91-93.

Miles, M. B.; Huberman, M. A. (1984). Qualitative Data Analysis. Beverly Hills: Sage Publications, Inc.

Moore, H. (1990). Paul Ricoeur: Action, Meaning and Text. Tilley, C. (Ed.), Reading Material Culture. Oxford: Basil Blackwell Ltd.

Mugijatna. (2014). The Representation of Muslims in Rudyard Kipling's Short Stories: A Postcolonial Perspective. Al-Jami'ah, 21(1), 127-48.

Mugijatna; Habsari, S. K.; Putri, Y. A. (2014). Rick Riordan's Intention in Writing Percy Jakcson and the Lightening Thief and the Reception of The Readers. Kata, 16 (2), 77 78.

Mugijatna; Habsari S.K.; Kusciati, K. P. (2019). The Representation of Muslims in Conrad's Trilolgy, Almayer's Folly, An Outcast of the Island, and The Rescue. JISED, 4 (16), 106-117.

Murray, M. (1975). Modern Critical Theory: A Phenomenological Introduction. Netherland: Martinus Nijhoff.

Nakjavani, E. (1996). Phenomenology and Theory of Literature: An Interview with Paul Ricoeur. Rice, P. and Waugh, P. (Eds). Modern Literary Theory. London: Arnold, 89-94.

Palmer, R. E. (2003). Hermeneutika, Teori Baru Mengenai Interpretasi. Penerjemah: Hery, M dan Muhammad, D. (Trans.) Yogyakarta: Pustaka Pelajar.

Poespowardojo, W. (1987). Interpretasi. Bandung: Remadja Pustaka CV.

Raja, M. A. (2007). Joseph Conrad: The Question of Racism and Representation of Muslim in His Malayan Works. Postcolonial Text, 3 (4), 1-13.

Ricoeur, P. (1975). Phenomenology and Hermeneutics. No\&urics, 9(1), Symposium Paper to read at the meeting of the Western Division of American Philosophical Association in Chicago, Illinois, 92- 94.

Simms, K. (2003). Paul Ricoeur. London and New York: Routledge.

Soekarno. (2015). Di Bawah Bendera Revolusi. Jakarta: Yayasan Bung Karno.

Wimsatt, W. K. Jnr. and C. B. Monroe. (1972A). "The intentional fallacy". Lodge, D. (Ed.), $20^{\text {th }}$ Literary Criticism. Essex, K: Longman Group Limited, 333-344.

Wimsatt, W. K. Jnr. and C. B. Monroe. (1972B). The affective fallacy. Lodge, D.(ed.), $20^{\text {th }}$ Literary Criticism. Essex, K: Longman Group Limited, 345-358.

Young, V. (1953). Lingard's Folly: The Lost Subject. The Kenyon Review, 15 (4), 522-539. Retrieved 19-09-2016 19:31 UTC, from http://www.jstor.org/stable/4333443. 